\title{
Peirce Studies in China in the 21th Century
}

\section{Yi Jiang and Binmin Zhong}

\section{OpenEdition}

\section{Journals}

Electronic version

URL: http://journals.openedition.org/ejpap/1062

DOI: 10.4000/ejpap.1062

ISSN: 2036-4091

\section{Publisher}

Associazione Pragma

\section{Electronic reference}

Yi Jiang and Binmin Zhong, "Peirce Studies in China in the 21th Century », European Journal of Pragmatism and American Philosophy [Online], VI-2 | 2014, Online since 24 December 2014, connection on 01 May 2019. URL : http://journals.openedition.org/ejpap/1062 ; DOI : 10.4000/ejpap.1062

This text was automatically generated on 1 May 2019.

\section{(c) (i) $\odot$}

Author retains copyright and grants the European Journal of Pragmatism and American Philosophy right of first publication with the work simultaneously licensed under a Creative Commons AttributionNonCommercial-NoDerivatives 4.0 International License. 


\title{
Peirce Studies in China in the 21th Century
}

\author{
Yi Jiang and Binmin Zhong
}

\section{AUTHOR'S NOTE}

This essay completes the symposium on "The Reception of Peirce in the World" appeared in the last issue of EJPAP, 6, 1.

1 Peirce is more and more recognized in Chinese academic circles as an encyclopedic philosopher. The study of Peirce in China over the past 60 years can be roughly divided into four periods: the obscure period (1950-80), the starting period (1981-91), the expanding period (1992-2002), and the deepening period (2003-13). During the obscure period (1950-80), the understanding of Peirce was very shallow, mainly because of a narrow political view that led to unjust criticisms of his philosophy. In the starting period (1981-91), thanks to a process of reformation that made a growth of domestic and international academic exchanges possible, people started to have access to some of Peirce's writings and other texts of pragmatism and scholars began to take a fair academic attitude to study his thought. In the expanding period (1992-2002), new abundant scholarly resources and the achievements of the previous period, brought Peirce scholarship to an unparalleled phase of maturity. We find a good deal of information about this time in Jianwu Lin's article, Comments on Peirce research in China in recent years. ${ }^{1}$ Finally, the deepening period (2003-13) is the best period of Peirce research in China. In the light of the situation of the translation of Peirce's works and the research progress of Peirce's thought in various fields, this paper tries to give an overall introduction to the research on Peirce's philosophy in China during the deepening period. 


\section{A Profile of Chinese Translations of Peirce's Works}

2 Although there were a few Chinese translations of Peirce's writings, prominently the two papers "How To Make Our Ideas Clear" and "The Fixation of Belief," Chinese philosophers have not been very familiar with Peirce's works for decades, except for the vague awareness that Peirce belonged to the first generation of the American pragmatists. But in the recent years, with revival of pragmaticism in China, more and more Chinese scholars have attempted to translate Peirce's writings into Chinese. The most valuable achievement is The Selected Writings of C. S. Peirce ${ }^{2}$ edited by Jiliang Tu and published by the Social Sciences Documentation Publishing House in Beijing in 2006. This anthology includes Chinese translations of twenty-eight important papers by Peirce, covering his main research areas: pragmaticism, epistemology, metaphysic, logic, semiotics, science, and religion. There is also another anthology on pragmatism, Meaning, Truth and Action, ${ }^{3}$ edited by Susan Haack and Bo Chen, published by Oriental Press in 2007, in which some of Peirce's papers are included. Also some secondary literature on Peirce has also been translated, such as de Waal's Peirce, ${ }^{4}$ and Brent's Charles Sanders Peirce: A life. ${ }^{5}$

Given the increasing interest in Peirce and his thought in China, the need for a Chinese translation of the Collected Papers seems to be most urgent now. Thus, a project for the translation has been started last year under the leadership of Yi Jiang. Also, a translation of the Essential Peirce, in two volumes, will be available soon.

\section{Recent Studies on Peirce in China}

\section{II.1 On Peirce's Epistemology}

4 The research on Peirce's epistemology is the emerging hot-spot in China. It mainly focuses on his conceptions of truth and his so-called anti-foundationalism, on which Chinese researchers have managed to cast some new light.

Qiangjin Shao and Wei Huang think that Peirce's view of truth directly derived from his logic. In Peirce's view, there are no basic beliefs which are absolutely true, and knowledge is a network always improving its own beliefs. For the authors, Peirce's conception of truth should be understood in relation to the process of belief fixation, which is not static, but rather a process of logical exploration. Absolute certainty, Absolute exactitude, and Absolute universality, cannot be achieved through reasoning. Through the free and interactive dynamics of the scientific community, the ultimate belief will get approval after an historical process of semiotic translation $7 .^{6}$

6 Yin Wang discusses Peirce's theory of truth together with his fallibilism. Science does not have its own certainty, the process of scientific logical reasoning can be wrong. Considering a thinking object as a fallibility itself, its significance lies in that it's impossible to make a certain essential attribute behind the object. The meaning of an object can only be given by a net of possible interactions and effects. Yin Wang thinks that the main target of Peirce's anti-foundationalism is Cartesian foundationalism. The most important point is that, in Peirce's view, everything is in-the-making, there are no basic beliefs which are privileged for our cognitive life. ${ }^{7}$ 
7 Lei Pan argues that, although Peirce has an anti-foundationalist approach in epistemology, he is still committed to some sort of soft foundationalism, which is mainly reflected in his view of the relationship between the basic belief and experience. For Peirce, human understanding does not come out of the blue, but results from a network of beliefs which play a foundational role. This network is not static and completely reliable, but will be continuously adjusted in practice. If accepting a hypothesis could lead to establish how reality is, we should treat that hypothesis as the object of a temporary faith. Otherwise, the faith (hypothesis) is wrong and needs to be given up. ${ }^{8}$

8 Liuhua Zhang discusses Peirce's epistemology from the point of view of continuity. He thinks that the concept of continuity occupies a central place in Peirce's philosophy. Peirce's continuous philosophy started from the analysis of mathematical continuum, developed in the direction of different areas, such as the theory of the universals, perception theory, physical and mental problems, etc., and finally resulted into a unitary philosophical system where "realism," "fallibilism" and "idealism" are interwoven. ${ }^{9}$

\section{II.2 On Peirce's Scientific Philosophy}

9 The research on Peirce's scientific philosophy has been a hot spot in recent years in China. Researches have been mainly preoccupied with the problem of qualia and Peirce's contribution to economics.

10 Yi Jiang points out the importance of the qualia problem. He argues that consciousness is an important part on contemporary philosophy of mind. The key to solve the problem of consciousness is how to understand the quale as a phenomenon of consciousness. The answer to the question is not just related to the materialist foundation of the philosophy of mind, but also to the foundations of the whole building of human knowledge. ${ }^{10}$ Ling Liu has also studied the history of the word "quale." Peirce, she says, is the first philosopher using the word "quale" in the modern sense and introducing the word in philosophy. A "quale" has some characteristics, like its ineffability associated with conscious experience and so on. Ling Liu stresses that we should pay more attention to Peirce and his use of the word "quale" in relation to the philosophy of C. I. Lewis. Also Shuyan Wang discusses the connotation of the word "quale" in Peirce's philosophy. She believes that Peirce treats qualia as objects in the sensory experience. However, this idea is faced with a series of difficulties, for example, it is hard to explain why different people can form different "qualia" from the same object. ${ }^{11}$

11 Weiguo Xiao thinks that Peirce pioneered scientific economics. Peirce discussed the costs and benefits of the scientific research, and demonstrated the view that the scientific research can effectively create new knowledge, once the need to balance the relationship between the costs and benefits is satisfied. Although Peirce's view about knowledge accumulation is questioned by many scholars today, his Peirce's pioneering contribution to scientific economics should not be overlooked. Qun Chen and Qiquan Gui argue that Peirce's pragmatism is a philosophy of economics. Peirce used economics theory to discuss the costs and benefits of scientific research, which illustrates the close ties between pragmatism and methodology in economics. ${ }^{12}$ 


\section{II.3 On Peirce's Philosophy of Logic} following areas: (1) the axiomatization of propositional logic; (2) the discovery of disjunctive normal form and conjunctive normal form; (3) the prediction about the truth table method; (4) the creation of a quantifier notation independently from Frege and the development of the theory of measure words almost at the same time; (5) a bud of prenex normal form and Skolem hull; (6) the development of the relationship logic; (7) the discovery of the completeness of the truth function of binary conjunctions Sheffer-stroke; (8) the development of three-valued logic; (9) distinguishing between first-order logic and higher-order logic; (10) the creation of the existential graphs. ${ }^{14}$ In addition, Xinwen Liu also believes that Peirce is the first person who makes reduction for the connecting word number of Boolean logic. ${ }^{15}$ an apagoge of statistical inference is used to describe inductive reasoning, and used the defense reasoning to defend inductive reasoning. But such a defense method encountered insurmountable difficulties. Peirce then put forward the type defense of non-probability as a supplement. However, it still failed to show the effectiveness of inductive reasoning. ${ }^{16}$ Mengdan Qian also points out that Peirce appealed to the self- correctiveness of inductive reasoning to defend the legality of inductive reasoning. Although inductive reasoning can be false, Peirce believed that by constant use of induction, we could finally get the right conclusion. Unfortunately, for Qian, there is no logical ground to believe that induction can make us more and more close to the true state of the nature. ${ }^{17}$

Siping Miao thinks that Peirce put forward the concept of abductive reasoning around 1866. The role of abductive reasoning is to put forth assumptions, and to prove the rightness or wrongness of a belief by the argument of the whole process of assumptiondeduction-induction. Abductive reasoning is an important method to obtain new knowledge and plays an important role in criminal investigation, processes of fact identification, and so on. ${ }^{18}$ Xiaoxue Rong and Jiangbo Zhao draw a comparison between Peirce and Hanson's abductive reasoning. They think that Hanson's research goes in the same direction of Peirce's. Being the logic of scientific discovery, only abduction can produce a real advancement in scientific knowledge. From the point of view of logical methods, both Peirce and Hanson's abductive reasoning is a weak form of reasoning; but if we treat abduction as a concept of methodology and connect it with the goal we want to realize, abduction becomes the pivotal factor in the logic of discovery. ${ }^{19}$ 


\section{II.4 On Peirce's Theory of Signs}

17 Chinese researches have been occupied with Peirce's theory of signs since the 1990s. In the past decade, scholars have continued to deepen into this territory, and at the same time the application of Peirce's theory of signs has seen an important development.

Lei Pan and Zhifang Zhu think that signs can only be understood in relation to the human mind, that is, signs lead to equivalent or more developed symbols in the people's minds. As Peirce suggested, the sign that the first sign causes is called the interpretant of the first sign. The thing which the sign represents is its object. The sign needs the help of an idea to represent the object, and the idea is the matrix of this expression type. At the same time, the sign, the object, and the interpretation, interact with each other. Each sign has its life within a network of interpretations, and has its solid foundation thanks to it. ${ }^{20}$ Xiaojun Su argues that Peirce's theory of signs is grounded on three general categories, which are closely linked and ultimately indivisible. He thinks that Peirce's theory of signs derives from Kant. Accordingly, the core idea of Peirce's theory of signs is that the existence of the object is not composed of thoughts, and that the interplay among objects, signs, and interpretants is the most import point to be explained. ${ }^{21}$

Naranbilig thinks that, in Peirce's theory of signs, relations of objects can be divided into "like," "refers to" and "symbol." By observing the phenomenon of art, we can find that all the three signs exist in the phenomenon, connecting with each other, and could not be absent, so they could be referred to as "the three dimensions of art." ${ }^{22}$ Ersu Ding believes that Peirce's theory of signs has a positive effect to the classification of Chinese characters. According to Peirce's theory, Chinese characters can be divided into "simple icons," whose structure cannot be subdivided, and "compound icons," whose structure can be divided further. The compound icon can be divided into two Meta-icons, in which one is relevant with the meaning of the compound icon, and the other is related to the pronunciation of the compound icon. ${ }^{23}$ Yun Duan discusses the guiding significance of Peirce's sign theory in poetry translation from threefold viewpoint: "physics characteristics," "indicative sense," and "psychological sense."24 Biyun Huang makes an analysis on the new generation network buzzwords in China under the guidance of Peirce's theory of signs. ${ }^{25}$

\section{II.5 On Peirce's Metaphysics}

Peirce's thought on metaphysics has been ignored by Chinese academic circles for a long time. Only ten years ago some scholars have tried to study this aspect of Peirce's philosophy.

21 Chengbing Wang and Jianwu Lin point out that strengthening the research of Peirce's metaphysics is of great significance. They think that the fundamental purpose of "Peirce's principle" is to clarify the meaning of metaphysical concepts. Peirce tried to determine the metaphysical faith underpinning the methods of scientific exploration; also, Peirce's scientific metaphysics has as its object the independent reality. At the same time, Peirce's view on what scientific metaphysics really is, is influenced by Kant's philosophy. Peirce learnt his lesson from Kant and tried to find the foothold of metaphysics, and eventually identified it with the scientific community. ${ }^{26}$ Lijing Zhang thinks that Peirce's theory of category established the metaphysical foundation of his fallibilism by relying on the 
concept of suspect. ${ }^{27}$ Peirce's categories include the categories of firstness, secondness, and thirdness. Each category has both a material and a formal aspect.

\section{II.6 On Peirce's Pragmaticism and his Status in the History of Philosophy}

Since the time of political reformation, which granted a new understanding of Peirce's pragmaticism, Chinese scholars have had the opportunity to engage in a deeper and wider discussion of Peirce's thought and its place in the history of philosophy.

Yi Jiang thinks that Peirce treated pragmaticism as a way of thinking, as a research methods, and as a way of living, rather than a philosophical theory. The starting point of his work is to study "how to make our ideas clear" and "how to determine our beliefs." Peirce's pragmaticism is further used as a method to investigate and clarify words meaning, especially words which play important roles in science and philosophy. ${ }^{28}$ Huaqing Ke claims that Peirce's pragmaticism is not a metaphysical principle, but a logic method. This logical method is the logic of abduction (abductive reasoning). In Peirce's thought, "abductive reasoning" has a higher position than "deductive reasoning" and "induction reasoning." 29

Duanxin Zhang thinks that "Peirce's principle" is the basis of pragmaticism. Due to various reasons, there has been a big misunderstanding of this principle in China over the past years. In order to grasp the real import of it, it is necessary to analyze the principle from the perspective of the theory of meaning, logic, and linguistics understood in semeiotic terms ${ }^{30}$ Yin Wang discusses the problem of the translation of the word "pragmaticism." ${ }^{31}$ Ruina Hu and Shuhui Wang point out that Peirce's theory of signs is closely associated with his pragmaticism, and find that anti-foundationalism is a common feature of both. ${ }^{32}$

Jiliang Tu argues that Peirce is a founder of American pragmatism, who put forward the basic ideas of pragmatism for the first time. At the same time, Peirce is not simply a pragmatist, but is widely involved in many fields of the natural sciences. After his death, his theory had a great impact on British and American academic circles, especially among pragmatists and analytic philosophers. ${ }^{33}$ Yin Wang also argues that Peirce's philosophy has an important position in the history of philosophy. In fact, a correct understanding of the relationship between American pragmatism and the modern western philosophy casts some light on the development of western philosophy. ${ }^{34}$

Fangtong Liu points out that pragmatism has an important significance in the process of the modern transformation of American philosophy. Peirce, as one of the main founders of pragmatism, developed a negation of Cartesian foundationalism, a critique of Kant's metaphysics, a demonstration of important tenets of practical philosophy, as well as important insights in the nature of faith and truth. All of these aspects reflect the important features of the modern transformation of American philosophy. Peirce broke through the shackles of former philosophy and provided a theoretical basis for the modern transformation of western philosophy. ${ }^{35}$ 


\section{Summary and Future Prospects for Peirce Studies in China}

In short, we find that studies on Peirce in China have made significant progress in the past decade. First, scholars increasingly realize the importance of Peirce, and the number of Peirce scholars, monographs, and papers is a growing reality. Second, the Chinese translation of Peirce's writings has made great progress. Many of Peirce's essays now have more accurate Chinese translations, and more secondary literature on Peirce has also been made available. Third, we also assist to an explosion of researches on Peirce in different fields. Studies in Peirce's epistemology, philosophy of science, logic, semiotics, metaphysics, pragmaticism, the place of Peirce in the history of philosophy, and the application of his theory of signs, etc., are at the center of a growing interest. Fourth, also the depth of the knowledge of Peirce's thought seems to extend continuously. In certain fields, such as pragmaticism, logic, and semiotics, the level of Chinese scholarship is getting higher. Finally, national and international communication on Peirce studies has improved for China in the past years. In 2005, a Sino-American dialogue on symbols and value has played a good role in promoting the communication of Peirce studies between China and the United States.

of course, China also faces some difficulties for continuing its research on Peirce. First, Chinese translations of Peirce's works are not able at the moment to meet the researchers' needs. We still lack a Chinese version of The Collected Papers of Charles Sanders Peirce, and many key words in Peirce's writings lack accurate Chinese translations. Second, the research fields of Peirce's thought need to expand. Chinese scholarship has virtually no knowledge about Peirce's achievements in astronomy, religious thought, artistic ideas, etc. Third, Chinese scholars have to develop a deeper comprehension of Peirce's philosophy. Peirce has profound thoughts, which require a tireless hermeneutic work. Fourth, the organization and internationalization of the research on Peirce are not sufficient. China does not have a specific institution for Peirce research, and international communication only relies on individual discussions. Nevertheless, we believe that by strengthening translations of Peirce's works, expanding the breadth and depth of Peirce research, and developing the exchanges and cooperation with among scholars from different countries, Peirce studies in China will ascend to a higher level.

\section{BIBLIOGRAPHY}

BRANT J., (2008), Charles Sanders Peirce: A life, translated by Shao Q. J., Shanghai, Shanghai People's Publishing House.

CHEN Q., \& GUI Q. Q., (2011), “The Relation between the Economics Methodology and Pragmatism,” Social Science Front, 2, 53-58. 
DE WAAL J., (2003), Peirce, translated by Hao C. X., Beijing: Zhonghua Book Company.

DING E., (2010), "Peircean Semiotics and the Categorization of Chinese Characters,"

Foreign Languages and Literatures, 4, 217-22.

DUAN Y., (2011), "Poetry Translation and Peircean Cognitive Semiotics Theory," Journal of Southwest University (Social Sciences Edition), 37, 5, 184-7.

HAACK S., \& CHEN B., (eds.), (2007), Meaning, Truth and Action: Pragmatism Classic Anthology, Beijing: Oriental Press.

HU R. N., \& WANG S. H.,(2007), “The Pragmatic Characteristicsof Peirce’s Semiotics

and Its Postmodern Trend," Science, Technology and Dialectics, 24, 4, 59-62.

HUANG B. Y., (2011), “The Difference between New and Traditional Network Buzzwords in the Perspective of Semiotics," Journalism and Communication Studies, 2, 106-12.

JIANG Y., (2009), “Consciousness, Quale and Anti-physicalism,” Guangming Daily, Sept, 7.

JIANG Y., (2013), “Pragmatism as A Kind of Method," Chinese Social Sciences Today, Jan, 14.

KE H. Q., (2010), “On Pragmaticism's Abduction Logic,” Philosophical Researches,

$7,82-8$.

LIN J. W., (2005), “Comments on Peirce Research in China in Recent Years,"

Philosophical Trends, 8, 57-62.

LIU F.T., (2007), "Peirce and the Modernization of Philosophy in American," Journal of Peking University (Philosophy and Social Sciences), 44, 4, 31-9.

LIU L., (2013), “The Source of the Conception of Quale," Journal of Dialectics of Nature, 35, 3, 60-70.

Liu X. W., (2006), “Peirce’s Existential Graphs study,” World Philosophy, 1, 94-103.

LIU X. W., (2011), “On Reduction of Logical Constants,” Philosophical Researches, 6, 115- 22.

MIAO S. P., (2011), “Abduction Reasoning and Its Application in the Proceedings," Jiangxi Social Sciences, 9,159-66.

NARANBILIG, (2012),“Three Dimensions in Art,” Journal of Art College of Inner Mongolia University, 9, 31, 5-9.

PAN L., (2011), “Anti-Foundationalism and Fallibilism: A Research on Peirce's Epistemology," Academic Research, 10, 28-32.

PAN L., \& ZHU Z. F., (2010), “The Semiotic Dimension of Peirce's Pragmatism,” Journal of Dialectics of Nature, 32, 189, 10-4.

QIAN M. D., (2010), “The Inductive Problem Study,” Intelligence, 27, 205-6.

RONG L. W., (2010), “Non-Probabilistic Justification of Induction and Its Difficulties," Journal of South China Normal University (Social Science Edition), 6, 88-94.

RONG X. X., \& ZHAO J. B., (2012), "Inference to the Best Explanation and Abduction," Journal of Dialectics of Nature, 34, 199, 13-8.

SHAO Q. J., \& Huang W., (2011), “The Practical Significance of Peirce's Truth Theory," Journal of Guangxi University, 33, 2, 69-72. 
SU X. J., (2012), “The Compatibility of Peirce Semiotics and Cognitive Linguistics," Journal of Suzhou University, 3, 134-7.

TU J. L., ed., (2006), Selected Writings of C. S. Peirce, Beijing, Publishing House of China's Social Sciences.

TU J. L., (2007), A History of American Philosophy (I), Wuhan: Wuhan University.

WANG C. B., \& Lin J. W., (2007), "Peircean View of Scientific Metaphysics," Jianghan Tribune, 5, 74-7.

WANG Y., (2005), “Review of American Pragmatism's Philosophical Foundation: To Understand Peirce's Philosophy and Pragmatism in Nietzsche's Doctrine," Proceedings of the International Academic Conference for Dewey Thought's Contemporary Significance, 1-4.

WANG Y., (2009), "Must Criticisms of Apriorism Leads to the Empirical? -A Discussion on the Erroneous Zone in Jamesian Understanding of Peirce's Philosophy," Journal of Shanghai Jiao Tong University, 17, 2, 58-63.

WANG Y., (2011), Nature and Origin: Phenomenological Annotationto Peirce's Pragmaticism Problems, Hangzhou, Zhejiang University Press.

XIAO W. G., (2009), “The Scientific Economy Found by the Philosopher Peirce," Studies in Philosophy of Science and Technology, 26, 5, 45-9.

ZHANG D. X., (2007), “On Peirce's Pragmaticism Principle,” Social Scientist, 6, 22-5.

ZHANG L. H., (2011), “Peirce's continuous philosophy: Realism, Fallibilism and Idealism," Proceedings of the International symposium on analytic philosophy: China and the world and the 7th national conference on analytic philosophy, 1-14.

ZHANG L. H., (2012), The Logic for Peirce's Philosophy, Shanghai: Shanghai People's Publishing House.

ZHANG L. J., (2009), "Suspect: the Reality, the Possible and the Potential - the Metaphysical Foundation of Peircean Fallibilism," Doctoral Dissertation, Tianjin, Nankai University.

\section{NOTES}

1. Lin J. W., (2005), "Comments on Peirce Research in China in Recent Years," Philosophical Trends, 8, 57-62.

2. Tu J. L. ed., (2006), The Selected Writings of C. S. Peirce, Beijing, Publishing House of China's Social Sciences.

3. Haack S., \& Chen B. ed., (2007), Meaning, Truth and Action: Pragmatism Classic Anthology, Beijing, Oriental Press.

4. De Waal J., (2003), Peirce, translated by Hao C. X., Beijing, Zhonghua Book Company.

5. Brant J., (2008), Charles Sanders Peirce: A life, translated by Shao Q. J., Shanghai, Shanghai People's Publishing House.

6. Shao Q. J., \& Huang W., (2011), “The Practical Significance of Peirce's Truth Theory,” Journal of Guangxi University, 33, 2, 69-72.

7. Wang Y., (2009), "Must Criticisms of Apriorism Leads to the Empirical? -A Discussion on the Erroneous Zone in Jamesian Understanding of Peirce's Philosophy," Journal of Shanghai Jiao Tong University, 17, 2, 58-63.

8. Pan L., (2011), “Anti-Foundationalism and Fallibilism: A Research on Peirce's Epistemology," Academic Research, 10, 28-32. 
9. Zhang L. H., (2011), "Peirce's continuous philosophy: Realism, Fallibilism and Idealism," Proceedings of the International symposium on analytic philosophy: China and the world and the 7th national conference on analytic philosophy, 1-14.

10. Jiang Y., (2009), "Consciousness, Quale and Anti-physicalism," Guangming Daily, Sep, 7.

11. Liu L., (2013), "The Source of the Conception of Quale," Journal of Dialectics of Nature, 35, 3, 60-70.

12. Xiao W. G., (2009), "The Scientific Economy Found by the Philosopher Peirce," Studies in Philosophy of Science and Technology, 26, 5, 45-9.

13. Zhang L. H., (2012), The Logic for Peirce's Philosophy, Shanghai, Shanghai People's Publishing House.

14. Liu X. W., (2006), “Peirce's Existential Graphs Study,” World Philosophy, 1, 94-103.

15. Liu X. W., (2011), “On Reduction of Logical Constants," Philosophical Researches, 6, 115-22.

16. Rong L. W., (2010), "Non-Probabilistic Justification of Induction and Its Difficulties," Journal of South China Normal University (Social Science Edition), 6, 88-94.

17. Qian M. D., (2010), “The Inductive Problem Study,” Intelligence, 27, 205-6.

18. Miao S. P., (2011), “Abduction Reasoning and Its Application in the Proceedings," Jiangxi Social Sciences, 9, 159-66.

19. Rong X. X., \& Zhao J. B., (2012), "Inference to the Best Explanation and Abduction," Journal of Dialectics of Nature, 34, 199, 13-8.

20. Pan L., \& Zhu Z. F., (2010), “The Semiotic Dimension of Peirce's Pragmatism," Journal of Dialectics of Nature, 32, 189, 10-4.

21. Su X. J., (2012), "The Compatibility of Peirce Semiotics and Cognitive Linguistics," Journal of Suzhou University, 3, 134-7.

22. Naranbilig, (2012), "Three Dimensions in Art," Journal of Art College of Inner Mongolia University, 9, 31, 5-9.

23. Ding E., (2010), "Peircean Semiotics and the Categorization of Chinese Characters," Foreign Languages and Literatures, 4, 217-222.

24. Duan Y., (2011), "Poetry Translation and Peircean Cognitive Semiotics Theory," Journal of Southwest University (Social Sciences Edition), 37, 5, 184-7.

25. Huang B. Y., (2011), “The Difference between New and Traditional Network Buzzwords in the Perspective of Semiotics," Journalism and Communication Studies, 2, 106-12.

26. Wang C. B., \& Lin J. W., (2007), "Peircean View of Scientific Metaphysics," Jianghan Tribune, 5, 74-7.

27. Zhang L. J., (2009), "Suspect: the Reality, the Possible and the Potential - the Metaphysical Foundation of Peircean Fallibilism," Doctoral Dissertation, Tianjin: Nankai University.

28. Jiang Y., (2013), "Pragmatism as A Kind of Method," Chinese Social Sciences Today, Jan, 14.

29. Ke H. Q., (2010), “On Pragmaticism's Abduction Logic,” Philosophical Researches, 7, 82-8.

30. Zhang D. X., (2007), “On Peirce's Pragmaticism Principle,” Social Scientist, 6, 22-5.

31. Wang Y., (2011), Nature and Origin: Phenomenological Annotation to Peirce's Pragmaticism Problems, Hangzhou, Zhejiang University Press, 10.

32. Hu R. N., \& Wang S. H., (2007), "The Pragmatic Characteristics of Peirce's Semiotics and Its Postmodern Trend," Science, Technology and Dialectics, 24, 4, 59-62.

33. Tu J. L., (2007), A History of American Philosophy (I), Wuhan, Wuhan University Press, 508-9.

34. Wang Y., (2005), "Review of American Pragmatism's Philosophical Foundation: To Understand Peirce's Philosophy and Pragmatism in Nietzsche's Doctrine," Proceedings of the International Academic Conference for Dewey Thought's Contemporary Significance, 1-4.

35. Liu F. T., (2007), "Peirce and the Modernization of Philosophy in American," Journal of Peking University (Philosophy and Social Sciences), 44, 4, 31-9. 


\section{ABSTRACTS}

C. S. Peirce has been considered in China as the pioneer of American pragmatism, not only within academic circles, but also in the public's perception. Nonetheless, some Chinese scholars still confuse his theory with that of the other two principal figures in classical pragmatism. However, there are a few Chinese scholars who clearly realize the difference between Peirce's pragmaticism and other forms of pragmatism. As a result, an increasing number of Chinese books and contributions focus on Peirce's philosophy. The Selected Writings of C. S. Peirce, edited by Jiliang $\mathrm{Tu}$, were published in 2006, and the translation of The Essential Peirce in two volumes is in process. The translation of The Collected Papers of C. S. Peirce in 8 volumes has been planned under the leadership of Yi Jiang. Chinese Peirce scholars are mainly concerned with the following topics: (1) the historical relation of Peirce to the pragmatist movement in the 19th century; (2) the contribution of Peirce's logic to the philosophy of logic; (3) Peirce as a pioneer of philosophy of science in the 20th century; (4) the comparative study of Peirce's semiotics and Saussure's linguistics; and (5) Peirce's unique place in the history of Western philosophy. There are a number of views about Peirce, but most Chinese scholars agree that his philosophy had a significant influence on 20th century philosophy in the West as well as in the rest of the world.

\section{AUTHORS}

\section{YI JIANG}

Beijing Normal University, China

jiangyi[at]bnu.edu.cn

\section{BINMIN ZHONG}

Beijing Normal University, China zhongbinmin@[at]foxmail.com 